\title{
Penerapan pembelajaran bermuatan sustainability di sekolah program adiwiyata untuk mendukung sustainable development
}

\section{Eny Hartadiyati Wasikin Haryanti ${ }^{*}$, Fibria Kaswinarni ${ }^{2}$}

\author{
1Universitas PGRI Semarang, Indonesia, email: hartadiyatieny@gmail.com \\ 2Universitas PGRI Semarang, Indonesia, email: fibriafifi81@gmail.com \\ *Koresponden penulis
}

\section{Info Artikel}

Diajukan: 31 Jan 2021

Diterima: 19 Jun 2021

Diterbitkan: 03 Jul 2021

\section{Keywords:}

iptek; training; online

learning; zoom aplication

\section{Kata Kunci:}

iptek; pelatihan; pembelajaran berbasis daring; aplikasi zoom

\section{Lisensi:}

cc-by-sa

\begin{abstract}
The Adiwiyata program is implemented in order to realize responsible school citizens in efforts to protect and manage the environment through good school governance to support Sustainable Development. SMAN 3 Demak is one of the schools that organizes the Adiwiyata Program. Several activities that have been carried out to support Sustainable Development include environmental hygiene, waste management and reforestation. However, the learning process has not been carried out to support Sustainable Development, it is necessary to implement Learning Containing Sustainability. The purpose of this service is to provide teachers with: (1) insight and understanding of Sustainable Development (2) compiling Learning Containing Sustainability. The methods used are counseling, workshop and mentoring. The results of the counseling activities on the understanding of Sustainable Development showed that $93.75 \%$ of the participants got a minimum score of 75 with complete criteria. As for the workshop activities on Learning Containing Sustainablity (embedding the concept of Sustainable Development in learning materials) it was seen that $87.5 \%$ of participants were at least quite successful. The results of these activities have met the planned output targets. The mentoring activities for learning teachers have been carried out in accordance with the learning materials in their respective classes.
\end{abstract}


(embedding konsep Sustainable Development dalam materi pembelajaran) terlihat $87,5 \%$ peserta minimal cukup berhasil. Hasil kegiatan tersebut sudah memenuhi target luaran yang sudah direncanakan. Adapun kegiatan pendampingan bagi guru pembelajaran sudah dilaksanakan sesuai dengan materi pembelajaran di kelas masing-masing.

\section{PENDAHULUAN}

Permen Lingkungan Hidup No. 5 Tahun 2013 tentang Pedoman Pelaksanaan Program Adiwiyata menyebutkan bahwa Program Adiwiyata adalah program untuk menwujudkan sekolah yang peduli dan berbudaya lingkungan. Dalam hal ini sekolah harus dapat melaksanakan program: (1) Pengembangan kebijakan sekolah peduli dan berbudaya lingkungan, (2) Pengembangan kurikulum berbasis lingkungan, (3) Pengembangan kegiatan lingkungan berbasis partisipatif, dan (4) Pengembangan dan pengelolaan sarana pendukung sekolah berbudaya lingkungan. Diharapkan melalui program ini dikemudian hari warga sekolah tersebut dapat turut bertanggung jawab dalam upaya-upaya penyelamatan lingkungan dan pembangunan berkelanjutan (Sustainable Development).

Berdasarkan hasil wawancara dengan guru dan observasi pelaksanaan Program Adiwiyata di Sekolah Menengah Atas Negeri 3 Kabupaten Demak, terlihat telah melaksanakan Program Adiwiyata tersebut terbukti adanya kegiatan pengelolaan sampah, kebersihan lingkungan, penghijauan lingkungan, pengadaan taman sekolah, sanitasi yang baik, air bersih, ruangan yang hemat energi, pembelajaran berbasis lingkungan dan sebagainya. Sebagai puncak kinerja yang baik maka SMA Negeri 3 Demak pada tahun 2018 telah mendapatkan penghargaan tingkat pencapaian sebagai Sekolah Adiwiyata Provinsi (Bidang 2 Dinas Lingkungan Hidup Kabupaten Demak, 2019).

Lebih lanjut, berdasarkan wawancara dengan beberapa guru disertai dengan menelaah dokumen perangkat pembelajaran diketahui bahwa pembelajaran berbasis lingkungan yang dilakukan terlihat masih dominan pada materi-materi tertentu yang bertema lingkungan seperti ekosistem, keanekaragaman hayati, dan pencemaran lingkungan. Agar proses pembelajaran berbasis lingkungan lebih dapat mendukung Sustainable Development maka pembelajaran tidak hanya memperhatikan aspek lingkungan tetapi harus meliputi tiga aspek yaitu sosial-budaya, ekonomi dan lingkungan (Rieckmann, M. Mindt, L. and and Gardiner, 2017, Leicht et al., 2018). Tiga aspek tersebut harus dapat menunjukkan bahwa kegiatan bidang sosial-budaya, ekonomi dan lingkungan tersebut saling berkaitan untuk memenuhi kebutuhan sekarang dan mampu meningkatkan mutu hidup generasi masa sekarang dan masa depan (Rosana, 2018).

Pembelajaran yang mendukung Sustainable Development dapat dilakukan dengan memasukkan aspek ekonomi, sosial-budaya dan lingkungan ke dalam setiap mata pelajaran (Suprastowo et al., 2010). Lebih fokus, aspek sosial-budaya, ekonomi, dan lingkungan disematkan dalam setiap konsepkonsep atau masing-masing Kompetensi Dasar (Rizqiyah \& Hartadiyati, 2017, 
Hartadiyati et al., 2017, Hartadiyati \& Rahmawati, 2018, Hartadiyati et al., 2019). Secara keseluruhan dalam pembelajaran akan memuat pola pikir sustainability, selanjutnya dinamakan Pembelajaran Bermuatan Sustainability.

Berdasarkan penjelasan di atas maka dibutuhkan proses Pembelajaran Bermuatan Sustainability dalam Program Adiwiyata untuk mendukung Sustainable Development. Salah satu keberhasilan proses pembelajaran adalah faktor guru (Zein, 2016), maka perlu ada peningkatan kinerja guru dalam proses pembelajaran dengan memberikan kepada guru: (1) wawasan dan pemahaman tentang Sustainable Development, (2) keterampilan penerapan Pembelajaran Bermuatan Sustainability (embedding konsep Sustianable Development pada materi pembelajaran) dalam sekolah Program Adiwiyata untuk mendukung Sustainable Development.

\section{METODE PELAKSANAAN}

Pelaksanaan Pengabdian Kepada Masyarakat ini dilakukan selama 2 bulan yaitu Februari sampai dengan Maret 2020. Kegiatan ini melibatkan khalayak sasaran adalah guru di SMAN 3 Demak dan diundang pula beberapa guru SMA yang ada di Kabupaten Demak. Adapaun metode yang digunakan secara bertahap yaitu memberikan penyuluhan dilanjutkan workshop dan tahap berikutnya adalah pendampingan, secara rinci sebagai berikut:

\section{Penyuluhan}

Kegiatan penyuluhan dilakukan pada awal kegiatan untuk memberikan pemahaman tentang Sustainable Development untuk mendukung Sekolah Program Adiwiyata. Kegiatan ini dilakukan dengan metode ceramah informatif, dan tanya jawab. Di akhir kegiatan penyuluhan dilakukan test tertulis subjective test. untuk mengukur pemahaman tentang Sustainable Development.

Pengukuran hasil test dilakukan menggunakan rating scale 1-4. Skor yang diperoleh peserta kemudian dikonversi menjadi nilai, sebagai berikut:

$$
\text { Nilai }=\frac{\text { skor yang didapat }}{\text { skor maksimal }} \times 100
$$

selanjutnya dikelompokkan menjadi tuntas dan tidak tuntas dengan ketentuan yang tercantum dalam Tabel 1.

Tabel 1. Kriteria Nilai Pemahaman tentang Sustainable Development

\begin{tabular}{cc}
\hline Rentang Nilai & Kategori \\
\hline Nilai $\geq 75,0$ & Tuntas \\
Nilai $<75,0$ & Tidak Tuntas \\
\hline
\end{tabular}

Bila tidak tuntas akan diberikan penjelasan secara individual. Hal ini penting karena akan mempengaruhi guru dalam mendesain Framework Pembelajaran Bermuatan Sustainability. 


\section{Workshop}

Pemahaman tentang Sustainable Development digunakan sebagai bekal untuk melakukan kegiatan workshop yaitu melakukan embedding konsep Sustainable Development (integrasi aspek sosial, ekonomi dan lingkungan) ke dalam materi pembelajaran. Pada kegiatan ini diawali dengan penjelasan dan demonstrasi oleh Tim Pengabdian kemudian dilanjutkan dengan praktik oleh peserta membuat Framework Pembelajaran Bermuatan Sustainability sesuai materi pembelajaran. Pada kegiatan ini dilakukan juga diskusi, presentasi dan tanya jawab untuk membahas hasil praktik dari peserta.

Keterampilan guru melakukan embedding konsep sustainability dalam materi pembelajaran dilakukan penilaian terhadap produk yang dibuat oleh peserta. Produk yang dibuat perserta diukur menggunakan rating scale 1-4. Skor yang diperoleh peserta kemudian dikonversi menjadi nilai, sebagai berikut:

$$
\text { Nilai }=\frac{\text { skor yang didapat }}{\text { skor maksimal }} \times 100
$$

Selanjutnya nilai dikelompokkan menjadi berhasil, cukup berhasil dan tidak berhasil dengan ketentuan tercantum di Tabel 2, sebagai berikut:

Tabel 2. Kriteri Produk Berupa Framework Pembeajaran Bermuatan Sustability

\begin{tabular}{cc}
\hline Rentang Nilai & Kategori \\
\hline Nilai $\geq 75,0$ & Berhasil \\
$25<$ Nilai $<75,0$ & Cukup \\
Nilai $\leq 25$ & Tidak berhasil \\
\hline
\end{tabular}

\section{Pendampingan}

Pendampingan dilaksanakan kepada peserta untuk melanjutkan Framework menjadi menjadi lebih sesuai dengan materi di kelas masingmasing.

\section{HASIL DAN PEMBAHASAN}

Kegiatan Pengabdian Kepada Masyarakat bertempat di SMAN 3 Kabupaten Demak. Hadir dalam kegiatan tersebut sejumlah 16 orang guru. Adapun hasil yang telah dicapai dalam kegiatan ini adalah:

\section{Penyuluhan}

Kegiatan penyuluhan di lakukan di bulan Februari 2020 dengan kegiatan memberikan penjelasan tentang Sustainable Development. Peserta diberikan pemahaman tentang pengertian Sustainable Development, dan tujuan SDGs (Sustainable Development Goals). Penyajian materi (Gambar 1) dilengkapi contoh pelaksanaan dan best practice pelaksanan setiap tujuan, sebagai contoh pemahaman penggunaan compost tea untuk meningkatkan pemahaman tentang Sustainable Development (Hartadiyati et al., 2020). 


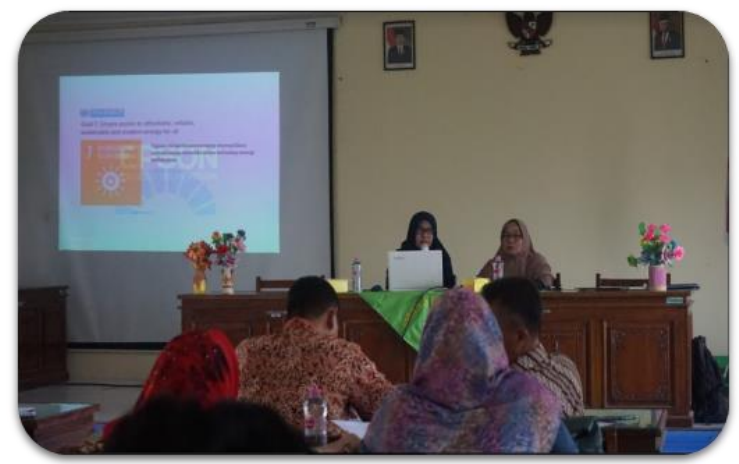

Gambar 1. Paparan tentang Sustainable Development

Hasil tes yang diberikan di akhir kegiatan penyuluhan (posttest) ditunjukkan pada Tabel 3.

Tabel 3. Nilai Pemahaman tentang SDGs (Sustainable Development Goals)

\begin{tabular}{cccc}
\hline Peserta & Skor & Nilai & Kriteria \\
\hline P-1 & 8 & 100 & Tuntas \\
P-2 & 8 & 100 & Tuntas \\
P-3 & 7 & 77,7 & Tuntas \\
P-4 & 8 & 100 & Tuntas \\
P-5 & 6 & 75 & Tuntas \\
P-6 & 8 & 100 & Tuntas \\
P-7 & 8 & 100 & Tuntas \\
P-8 & 7 & 77,7 & Tuntas \\
P-9 & 6 & 75 & Tuntas \\
P-10 & 8 & 100 & Tuntas \\
P-11 & 8 & 100 & Tuntas \\
P-12 & 8 & 100 & Tuntas \\
P-13 & 8 & 100 & Tuntas \\
P-14 & 5 & 62,5 & Tidak Tuntas \\
P-15 & 8 & 100 & Tuntas \\
P-16 & 8 & 100 & Tuntas \\
\hline
\end{tabular}

Tabel 3 menunjukkan ada 15 peserta atau sebanyak $93,75 \%$ yang mendapat nilai minimal 75 , dan sebanyak $6,25 \%$ mendapatkan nilai kurang dari 75. Hal ini dikatakan bahwa penjelasan tentang Sustainable Development sudah sesuai dengan target luaran yaitu sebanyak $90 \%$ peserta memahami materi. Hal ini disebabkan sudah diupayakan penjelasan dengan cara informatif dengan media powerpoint yang dibagikan dan tanya jawab selama proses penyuluhan berlangsung dengan penuh humanis dan penjelasan dilakukan secara andragogy. Adapun secara rinci pemahaman peserta berkaitan dengan materi Sustainable Development ditunjukkan pada Tabel 4 dengan hasil yaitu minimal $75 \%$ peserta mendapat nilai 100 pada semua aspek. 
Tabel 4. Pemahaman Peserta tentang Sustainable Development

\begin{tabular}{clcccc}
\hline \multirow{2}{*}{$\begin{array}{c}\text { No. } \\
\text { Soal }\end{array}$} & Aspek & \multicolumn{3}{c}{$\begin{array}{c}\text { Jumlah Peserta dalam Persen } \\
\text { berdasarkan Nilai }\end{array}$} \\
\cline { 3 - 6 } & & $\mathbf{1 0 0}$ & $\mathbf{7 5}$ & $\mathbf{5 0}$ & $\mathbf{2 5}$ \\
\hline 1 & Konsep Sustainable Development & $87,5 \%$ & $12,5 \%$ & 0 & 0 \\
2 & Issue penting untuk mewujudkan SDGs & $75 \%$ & $25 \%$ & 0 & 0 \\
\hline
\end{tabular}

Tabel 3 dan Tabel 4 membuktikan bahwa penjelasan materi yang dilakukan dengan ceramah informatif berbantuan media powerpoint dan tanya jawab menyebabkan para peserta dapat memahami dengan baik, seperti juga yang dilakukan oleh (Firmansyah et al., 2020) bahwa penggunaan powerpoint dapat meningkatkan pemahaman konsep. Demikian juga dapat menimbulkan hasil belajar (Sulasteri et al., 2018) dan minat (Khaerunnisa et al., 2018). Peserta juga sangat antusias dalam mengajukan pertanyaan-pertanyaan seperti pada Gambar 2. Peserta memiliki keinginan yang tinggi untuk mengetahui tentang 17 tujuan pada SDGs (Sustainable Development Goals). Ketujuh belas tujuan SDGs inilah selanjutnya yang akan menjadi bekal guru dalam memilih persoalan untuk dibuat domain konteks berdasarkan materi pembelajaran.

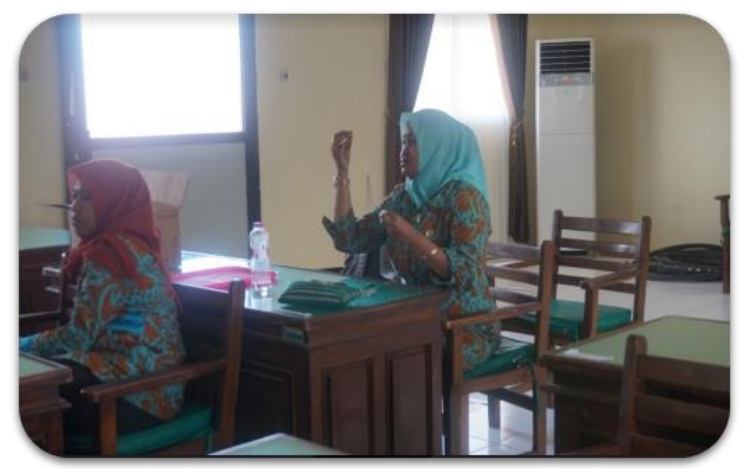

Gambar 2. Salah Satu Peserta Menyampaikan Pertanyaan

Meskipun demikian, tampaknya peserta masih merasa kesukaran untuk menemukan permasalahan terkait SDGs. Berdasarkan hasil tanya jawab lisan bahwa kesulitan peserta disebabkan oleh keterbatasan keluasan wawasan dan sumber belajar maupun sumber informasi yang dimiliki guru. Menurut peserta harus banyak mencari diberbagai sumber informasi. Walaupun demikian sebenarnya peserta sudah menunjukkan antusiasme untuk mencari informasi melalui internet pada saat menjawab soal.

\section{Workshop}

Setelah selesai kegiatan penyuluhan, dilanjutkan dengan kegiatan workshop. Pada kegiatan workshop Tim Pengabdian melakukan demonstrasi tentang cara melakukan embedding konsep Sustainable Development pada materi pembelajaran (Framework Pembelajaran 
Bermuatan Sustainability) (Gambar 3). Kemudian diikuti praktik oleh peserta.

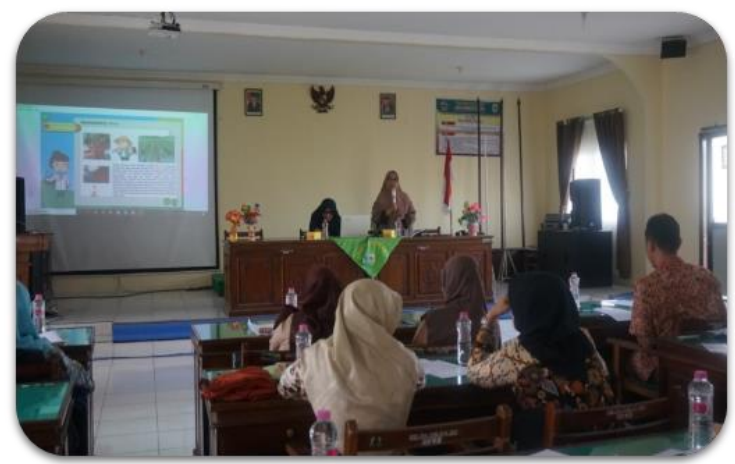

Gambar 3. Demonstrasi embedding konsep Sustainable Development dalam materi pembelajaran

Pada workshop, peserta melakukan embedding konsep Sustainable Development dalam materi pembelajaran (Framework Pembelajaran Bermuatan Sustainability), nampak pada Gambar 4 peserta dengan antusias menyelesaikan produk workshop. Adapun hasil penilaian ditunjukkan pada Tabel 5.

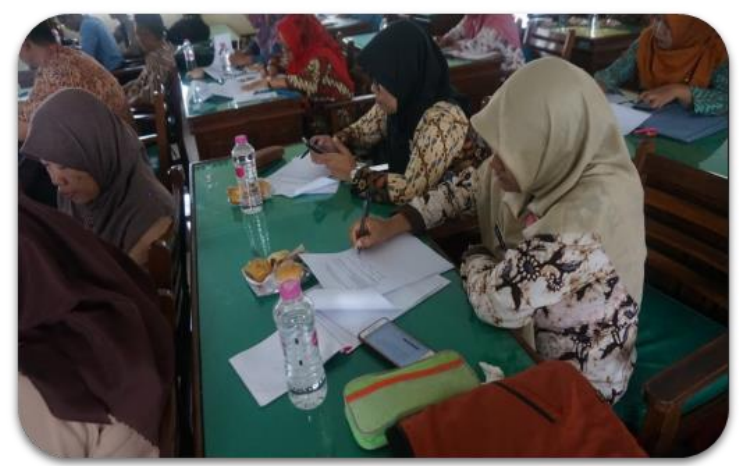

Gambar 4. Peserta sedang mengerjakan posttest dan membuat produk Framework Sustainability dalam materi pembelajaran

Tabel 5. Nilai Produk Framework Sustainability dalam Materi Pembelajaran

\begin{tabular}{cccc}
\hline Peserta & Skor & Nilai & Kriteria \\
\hline P-1 & 4 & 100 & Berhasil \\
P-2 & 4 & 100 & Berhasil \\
P-3 & 2 & 50 & Cukup \\
P-4 & 2 & 50 & Cukup \\
P-5 & 3 & 75 & Berhasil \\
P-6 & 4 & 100 & Berhasil \\
P-7 & 1 & 25 & Tidak Berhasil \\
P-8 & 3 & 75 & Berhasil \\
P-9 & 2 & 50 & Cukup \\
\hline
\end{tabular}




\begin{tabular}{cccc}
\hline Peserta & Skor & Nilai & Kriteria \\
\hline P-10 & 4 & 100 & Berhasil \\
P-11 & 2 & 50 & Cukup \\
P-12 & 2 & 50 & Cukup \\
P-13 & 4 & 100 & Berhasil \\
P-14 & 3 & 75 & Berhasil \\
P-15 & 1 & 25 & Tidak Berhasil \\
P-16 & 2 & 50 & Cukup \\
\hline
\end{tabular}

Tabel 5 menunjukkan bahwa $87,5 \%$ peserta minimal cukup berhasil. Hal ini sudah memenuhi target luaran bahwa $85 \%$ peserta minimal cukup berhasil melakukan embedding konsep Sustainable Development dalam materi pembelajaran. Dengan kata lain bahwa peserta sudah dapat membuat Framework Pembelajaran Bermuatan Sustainability. Hasil yang didapatkan ditentukan dalam kriteria minimal cukup karena embedding 3 aspek sustainability secara terintegrasi ke dalam materi pembelajaran membutuhkan pemahaman yang menyeluruh berkaitan dengan materi, pemilihan konteks global atau nasional atau personal yang kekinian dan sesuai dengan permasalahan sehari-hari. Dapat dicontohkan Guru mengajak siswa untuk mengeksplorasi kegiatan pengasapan ikan di Desa Banggi berdasarkan aspek Sustainable Development, yaitu konsep ekonomi, sosial budaya dan lingkungan dimulai dari merumuskan masalah, mencari solusi hingga menguji solusi menggunakan fakta empiris terkait dengan sistem pernapasan (Hartadiyati et al., 2021).

Berdasarkan target luaran yang dicapai disebabkan oleh kegiatan yang dilakukan dengan melibatkan peserta untuk aktif secara langsung dapat memberikan minat dan pemahaman bagi pesertanya (Çelik, 2018) salah satunya adalah kegiatan workshop (Muslihudin, 2016).

\section{Pendampingan}

Pendampingan bagi peserta dilakukan untuk menyempurnakan Framework Pembelajaran Bermuatan Sustainability menjadi lebih operasional untuk pelaksanaan pembelajaran. Kegiatan pendampingan ini menghasilkan Framework Pembelajaran Bermuatan Sustainability sesuai materi pembelajaran di kelas masing-masing. Keberhasilan kegiatan pendampingan kepada guru dikarenakan disesuaikan dengan kondisi personal masing-masing guru (Dalilah, 2019).

\section{KESIMPULAN}

Setelah kegiatan Pengabdian Kepada Masyarakat ini menghasilkan pengetahuan baru bagi guru yang sebelumnya belum pernah dipelajari dan dipahami tentang Sustainable Development, didapatkan sebanyak 93, 75\% peserta memahami Sustainable Development. Demikian pula kegiatan ini memberikan suatu pembelajaran inovatif yang baru yang belum pernah dilakukan oleh guru yaitu menerapkan Pembelajaran Bermuatan Sustainability, 
didapatkan sebanyak $87,50 \%$ peserta berhasil melakukan embedding konsep Sustainable Development dalam materi pembelajaran (membuat Framework Pembelajaran Bermuatan Sustainability). Hasil tersebut di atas sudah sesuai dengan target luaran yang telah direncanakan, yaitu: Ada sejumlah $90 \%$ guru dalam kategori tuntas dalam memahami konsep Sustainable Development. Sebanyak $85 \%$ guru minimal cukup berhasil membuat Framework Pembelajaran Bermuatan Sustainability. Dengan demikian SMAN 3 Demak sudah dapat menerapkan Pembelajaran Bermuatan Sustainability dalam Program Sekolah Adiwiyata untuk mendukung Sustainable Development. Untuk lebih menyiapkan guru dalam menerapkan Pembelajaran Bermuatan Sutainability dibutuhkan pendampingan yang efektif karena materi pembelajaran sangat bervariasi dan embedding yang tepat dari aspek sosialbudaya, ekonomi dan lingkungan.

\section{DAFTAR RUJUKAN}

Bosacco, S. J. (1986). Lumbar discography: Redefining its role with intradiscal therapy. Orthopedics, 9(3), 399-401. https://doi.org/10.3928/01477447-19860301-14

Çelik, H. C. (2018). The effects of activity based learning on sixth grade students' achievement and attitudes towards mathematics activities. Eurasia Journal of Mathematics, Science and Technology Education, 14(5), 1963-1977. https://doi.org/10.29333/ejmste/85807

Dalilah, I. (2019). Strategi Pendampingan Berkelanjutan sebagai Alternatif Peningkatan Kompetensi Guru dalam Penggunaan Media Pembelajaran Berbasis IT. JPDI (Jurnal Pendidikan Dasar Indonesia), 4(2), 59. https://doi.org/10.26737/jpdi.v4i2.1690

Firmansyah, A. W., Sumartini, \& Kurniawati, S. (2020). Pengaruh Penggunaan Media Powerpoint ( Studi Eksperimen Pada Siswa Kelas XI SMA Negeri 11 Bandung. Jurnal Pendidikan Ekonomi Indonesia, 1(1), 1-8.

Hartadiyati, E., Rizqiyah, K., Wiyanto, Rusilowati, A., \& Prasetia, A. P. B. (2017). The Integrated Model of Sustainability Perspective in Spermatophyta Learning Based on Local Wisdom. Journal of Physics: Conference Series, 895(1), 1-8. https://doi.org/10.1088/1742-6596/895/1/012051

Hartadiyati, E., Wiyanto, \& Rusilowati, A. (2020). The compost tea on hydroponics system used to increase understanding of Sustainable Development for high school student in Adiwiyata program. Journal of Physics: Conference Series, 1567(2). https://doi.org/10.1088/17426596/1567/2/022060

Hartadiyati, E., Wiyanto, Rusilowati, A., \& Priyono, A. (2019). Representation of sustainability concept in prospective biology teacher learning. Journal of Physics: Conference Series, 1321(3). https://doi.org/10.1088/17426596/1321/3/032053

Hartadiyati, E, Nurdianawati, S., Rusilowati, A., \& Ngabekti, S. (2021). Smoking fish in Banggi Village in learning of respiration system based on sustainable development. Journal of Physics: Conference Series, 1918, 1-6. https://doi.org/10.1088/1742-6596/1918/5/052078 
Hartadiyati, Eny, \& Rahmawati, M. (2018). Sustainability in the Framework of Pedagogy Content Knowledge for Prospective Teacher in Teaching the Materials of Female Reproductive System To Improve Students Science Literacy. Unnes Science Education Journal, 7(24), 281-289. https://doi.org/10.15294/USEJ.V7I3.26684

Khaerunnisa, F., Sunarjan, Y., \& Atmaja, H. T. (2018). Pengaruh Penggunaan Media Power Point Terhadap Minat Belajar Sejarah Siswa Kelas X SMA Negeri 1 Bumiayu Tahun Ajaran 2017/2018. Indonesian Journal of History Education, 6(1), 31-41.

Leicht, A., Heiss, J., \& Byun, W. J. (2018). Issues and trends in education for sustainable development. Paris, France: UNESCO Publishing, 2018.

Muslihudin, M. (2016). Meningkatkan Kemampuan Guru Dalam Pembuatan Media Pembelajaran Melalui Kegiatan Workshop. P2M STKIP Siliwangi, 3(2), 51. https://doi.org/10.22460/p2m.v3i2p51-58.627

Rieckmann, M. Mindt, L. and and Gardiner, S. (2017). Education for Sustainable Development Goals Learning Objectives. United Nations Educational, Scientific and Cultural Organization.

Rizqiyah, K., \& Hartadiyati, E. (2017). a Study of Students' Entrepreneur Concepts and Interests in Sustainabile Learning Concept in Spermatophyta Materials of Study. Unnes Science Education Journal, 6(2), 1655-1661. https://doi.org/10.15294/usej.v6i2.16413

Rosana, M. (2018). Kebijakan Pembangunan Berkelanjutan Yang Berwawasan Lingkungan di Indonesia. Jurnal KELOLA : Jurnal IImu Sosial, 1(1), 148163. https://doi.org/10.15575/jk.v1i1.4128

Sulasteri, S., Rusydi Rasyid, M., \& Akhyar, M. (2018). Pengaruh Penggunaan Media Pembelajaran Berbasis Media Presentasi Terhadap Minat Dan Hasil Belajar Matematika. MaPan: Jurnal Matematika Dan Pembelajaran, 6(2), 221-236. https://doi.org/10.24252/mapan.2018v6n2a8

Suprastowo, P., Sisdiana, E., Listiawati, N., Sumantri, D., Martini, A, I, D., Sudiyono, \& Supriyadi, T. (2010). Model Pendidikan untuk Pembangunan Berkelanjutan Kegiatan Intrakurikuler. Pusat Penelitian Kebijakan Badan Penelitian dan Pengembangan Kementerian Pendidikan Nasional.

Zein, M. (2016). Peran guru dalam pengembangan pembelajaran. Jurnal Inspiratif Pendidikan, V(2), 274-285. https://doi.org/10.24252/ip.v5i2.3480 